\title{
PERANAN KOMPETENSI PEDAGOGIK GURU DAN KEAKTIFAN BELAJAR SISWA PADA MATA PELAJARAN IPS MELALUI PEMBELAJARAN DALAM JARINGAN DI SMP N 2 CEPIRING KENDAL
}

\author{
Tri Wulan Sari, Fredy Hermanto ${ }^{凶}$ \\ Prodi Pendidikan Ilmu Pengetahuan Sosial, Fakultas Ilmu Sosial, Universitas Negeri Semarang, Indonesia
}

\begin{tabular}{l} 
Info Artikel \\
\hline Sejarah Artikel: \\
Disubmit: Januari 2021 \\
Direvisi: Februari 2021 \\
Diterima: Maret 2021 \\
\hline Keywords: \\
Teacher Pedagogic \\
Competence, Learning \\
Activeness, Social Studies \\
Learning.
\end{tabular}

\begin{abstract}
Sari
Tujuan dilaksankannya penelitian ini yaitu untuk mengetahui kompetensi pedagogik guru IPS dan keaktifan belajar siswa dalam proses pembelajaran IPS dan kendala guru IPS mengajarkan materi melalui pembelajaran dalam jaringan di SMP N 2 Cepiring Kendal. Hasil penelitian menunjukkan bahwa guru Guru IPS di SMP N 2 Cepiring Kendal memiliki peranan penting dalam keaktifan belajar siswa dengan tetap melaksanakan komponen pedagogik guru yang harus dimilikinya, antara lain kemampuan menguasai karakteristik siswa, kemampuan menguasai teori belajar, kemampuan mengembangkan teori kurikulum, kemampuan menguasai potensi peserta didik, dan kemampuan memanfaatkan teknologi informasi dan komunikasi. Keaktifan siswa dalam proses pembelajaran dapat dilihat dari kemampuan siswa dalam menangkap materi pembelajaran yang dapat dilihat dari berbagai hal seperti menyimak, berdiskusi, dan mengutarakan pendapat selama proses belajar mengajar.
\end{abstract}

\section{Abstract}

The aim of the research of this study was to determine the pedagogical competence of social studies teachers and student learning activeness in the social studies learning process and social studies teacher schools through online learning at SMP N 2 Cepiring Kendal. The results showed that the social studies teacher at SMP N 2 Cepiring Kendal has an important role in student learning activeness by continuing to implement the pedagogical components of the teacher that they must have, including the ability to master student material, the ability to master learning theory, the ability to develop curriculum theory, master potential abilities. learners, and take advantage of information and communication technology. The activeness of students in the learning process can be seen from the ability of students to capture learning material which can be seen from various things such as listening, discussing, and expressing opinions during the teaching and learning process.

(c) 2021 Universitas Negeri Semarang

\begin{tabular}{lc}
\hline Alamat korespondensi: & E-ISSN 2685-4929 \\
Gedung C1, Lantai 1, FIS UNNES & \\
Kampus Sekaran, Gunungpati, Semarang, 50229 & \\
Email: fredy@mail.unnes.ac.id & \\
\hline
\end{tabular}




\section{PENDAHULUAN}

Pendidikan pertama berada di lingkungan keluarga, di mana orang tua berperan sebagai pendidik bagi anak-anaknya. Begitu pula di sekolah siswa dididik oleh guru, pendidikan membantu anak-anak dalam proses kemandirian, mengenal dunia luar yang sebelumnya belum ia dapatkan. Pendidikan berfungsi juga mengembangkan potensi yang dimiliki oleh anak-anak serta karakteristik pribadi agar ke arah yang positif. Saat ini dunia pendidikan semakin berkembang pesat begitu juga dengan persoalan pendidikan bermunculan, salah satunya yaitu persoalan kompetensi mengajar guru. Guru sebagai tokoh utama di dalam kelas bagi siswanya, guru pula sebagai tenaga pendidik yang berwenang dan bertanggungjawab terhadap pendidikan siswa. Berhubungan dengan siswa, adakalanya guru mempunyai kompetensi yang baik pada saat pembelajaran guru juga berperan sebagai alat pendidikan, dan dapat berkaitan dengan fungsi guru dalam memperhatikan perilaku siswa belajar.

Kompetensi mengajar harus dimiliki oleh seorang guru untuk menguasai pembelajaran kepada siswa. Menurut Ramayulis (2013:18) tugas guru adalah membimbing, mengarahkan, memberi pengetahuan, membina akhlak, etika, moral, mental dan spiritual serta mempersiapkan murid agar siap menghadapi masa depan dengan penuh keyakinan serta percaya diri, sehingga dapat melaksanakan tugasnya sebagai hamba Allah di muka bumi dengan baik. Profesi guru inilah yang tertuang dalam UU No. 14 Tahun 2005 Pasal 8 menyatakan bahwasanya guru wajib memiliki kualifikasi akademik, kompetensi, sertifikat pendidikan, sehat jasmani, dan rohani, serta memiliki kemampuan untuk mewujudkan pendidikan nasional.
Menurut Undang-Undang Republik Indonesia No. 14 Tahun 2005 Pasal 8 Ayat 10 bahwa kompetensi adalah seperangkat pengetahuan, keterampilan, dan perilaku yang harus dimiliki, dihayati, dan dikuasai oleh guru atau dosen dalam melaksanakan tugas keprofesionalannya. Kompetensi dapat dinyatakan bahwa ada empat kompetensi yang harus dimiliki guru sebagai agen pembelajaran. Empat kompetensi itu adalah kompetensi pedagogis, kompetensi kepribadian, kompetensi profesional, dan kompetensi sosial. Kompetensi pedagogis yaitu kemampuan mengolah pembelajaran siswa. Kompetensi kepribadian yaitu guru memiliki sifat atau tabiat berakhlak mulia, arif, dan berwibawa serta menjadi teladan siswa. Kompetensi profesional yaitu kemampuan penguasaan materi pelajaran secara luas dan mendalam. Sedangkan kompetensi sosial yaitu guru yang mempunyai kemampuan untuk berkomunikasi dan berinteraksi secara efektif dan efisien dengan siswa, sesama guru, wali siswa, dan masyarakat sekitar. Empat kompetensi ini sangat berkaitan dengan proses pembelajaran di dalam maupun di luar kelas.

Berdasarkan keempat kompetensi yang harus dimiliki guru, kompetensi pedagogis merupakan kompetensi yang penting karena dapat menentukan kualitas mutu pendidikan. Kompetensi pedagogis yang dimiliki guru akan membawa dampak bagi siswa karena guru yang memiliki kompetensi ini cenderung menjadikan pembelajaran dikelas menjadi lebih menyenangkan dan tidak membosankan. Siswa merupakan hal yang utama selain guru, dalam pendidikan pasti ada bentuk simbiosis mutualisme yang saling menguntungkan antara guru dan siswa, siswa yang membutuhkan ilmu agar mendapatkan pengetahuan dan memiliki wawasan, kemudian guru yang mengajar siswa agar menjadi berilmu. Guru dalam penguasaan penyampaian materi secara mendalam dapat 
melibatkan siswa dengan keaktifan, bentuk keaktifan siswa dapat dilihat dari proses pembelajaran berlangsung.

Keaktifan bagi siswa berwujud perilaku seperti mencari sumber informasi yang dibutuhkan, menganalisis hasil percobaan, mempunyai rasa ingin tahu, melakukan percobaan, membuat karya tulis, membuat kliping dan perilaku sejenis lainnya. Belajar aktif ditunjukkan dengan adanya ketertiban yang tinggi dalam proses belajar. Sikap keaktifan siswa dalam proses pembelajaran terbentuk atas komponen kompetensi yang maksimal dari guru salah satunya kemampuan penguasaan materi secara mendalam atau disebut kompetensi profesional guru. Berdasarkan hasil observasi melalui pengamatan dan wawancara yang dilakukan peneliti di SMP N 2 Cepiring dengan salah satu guru IPS mengampu kelas VIII telah memberikan informasi mengenai kegiatan belajar mengajar, bahwasanya guru pengampu mata pelajaran IPS di SMP N 2 Cepiring terdapat 3 orang guru dengan latar belakang pendidikan yang berbeda. Adapun latar belakang pendidiknya yaitu Sarjana Ekonomi (S.E), Sarjana Pendidikan Geografi (S.Pd.), dan Sarjana Pendidikan Ekonomi Koperasi (S.Pd.) karena belum adanya guru yang memiliki konsep pengembangan IPS dan dengan keterbatasan penguasaan pengetahuan bidang studi. Proses penyampaian materi pembelajaran IPS kepada siswa kurang dapat berjalan maksimal dan baik. Dampak dari pedagogis guru yang kurang ini menjadikan keterlibatan siswa untuk aktif memberi tanggapan pada guru dalam menyampaikan materi yang diajarkan masih kurang. Hal ini dibuktikan dengan banyaknya siswa terlihat ketika pembelajaran IPS berlangsung ada yang mengantuk, ada yang bermain sendiri, ada yang mengobrol dengan temannya, dan ada juga tidur dibangku belakang sendiri diam saat ditanya, kurang memperhatikan dan sebagainya. Selain itu, siswa juga ada yang mengalami kesulitan dalam memahami IPS pada materi-materi tertentu. Akan tetapi, mereka merasa enggan untuk bertanya kepada guru mengenai materi yang belum dipahami. Berdasarkan latar belakang tersebut, peneliti tertarik untuk meneliti yang berhubungan dengan kompetensi guru dan keaktifan belajar siswa. Judul yang diangkat peneliti yaitu "Peranan Kompetensi Pedagogik Guru dan Kaeaktifan Belajar Siswa Pada Mata pelajaran IPS melalui Pembelajaran dalam Jaringan di SMP N 2 Cepiring Kendal".

\section{METODE}

Penelitian ini merupakan penelitian kualitatif. Penelitian kualitatif merupakan suatu rangkaian kegiatan atau proses penyaringan data dan informasi yang sewajarnya mengenai suatu masalah dalam suatu kondisi aspek tertentu pada objeknya (Sugiyono, 2010). Penelitian ini berusaha mengungkapkan keterangan peranan kompetensi guru pada mata pelajaran IPS serta mengembangkan keaktifan siswa dalam kegiatan belajar. Lokasi penelitian berada di SMP N 2 Cepiring Kendal.

Fokus penelitian dalam hal ini adalah membahas tentang Peranan Kompetensi Pedagogik Guru dan Keaktifan Belajar Siswa Pada Mata Pelajaran IPS melalui dalam jaringan meliputi kompetensi pedagogik guru IPS melalui pembelajaran dalam jaringan, keaktifan belajar siswa mata pelajaran IPS melalui pembelajaran dalam jaringan di, dan kendala guru IPS dalam mengajarakan materi melalui pembelajaran dalam jaringan di SMP N 2 Cepiring Kendal. . Sumber data dalam penelitian ini meliputi data primer dan sekunder. Data primer diperoleh melalui observasi dan wawancara yang dilakukan dengan informan atau subyek penelitian. Sumber data sekunder berasal dari data yang 
diperoleh tidak langsung atau menggunakan perantara. Teknik pengumpulan data dilakukan dengan cara observasi, wawancara, dan dokumentasi. Uji validitas data yang digunakan dalam penelitian ini adalah triangulasi sumber dan triangulasi teknik. Uji keabsahan data yang digunakan dalam penelitian ini adalah model interaktif Miles Huberman berupa pengumpulan data, reduksi data, penyajian data, dan penarikan kesimpulan atau verifikasi.

\section{HASIL DAN PEMBAHASAN}

SMP N 2 Cepiring Kendal terletak di J1. KH Ibrahim RT 01 RW 03 Kelurahan Kangkung, Kecamatan Kangkung, Kabupaten Kendal, Jawa Tengah. Luas area tanah sekolah 19,320 $\mathrm{m}^{2}$ serta memilik letak yang strategis dipinggir jalan dan berada di samping area persawahan menjadikan suasana di sekitar asri walaupun berada di samping Pasar Kecamatan. Lokasi SMP N 2 Cepiring Kendal sangat strategis yakni berdekatan secara langsung dengan jalan $\mathrm{KH}$ Ibrahim dan jalan $\mathrm{KH}$ Ustman yang memudahkan akses transportasi umum. Lokasi sekolah yang berdekatan dengan pemukiman penduduk pun menjadi lokasi yang sangat bernilai khususnya dari segi kedekatan lokasi sekolah dengan waktu tempuh siswa berangkat menuju sekolah. SMP N 2 Cepiring Kendal merupakan sekolah yang terakreditasi A di wilayah Kabupaten Kendal yang dilengkapi berbagai sarana prasarana seperti gedung sekolah yang terdiri dari 15 (lima belas) kelas yang menunjang terciptanya kualitas pendidikan.

Siswa di SMP N 2 Cepiring Kendal merupakan mereka yang telah diterima melalui proses seleksi dan pendaftaran. Siswa kelas VII dibagi dalam 5 kelas, yaitu VII A hingga VII E. Jumlah siswa per kelas antara 22-32 siswa sehingga jumlah siswa secara keseluruhan kelas VII adalah 140 orang, begitu pun dengan siswa di kelas VIII dan XI. Siswa di kelas VIII terdiri dari kelas VIII A hingga VIII E dengan rata-rata jumlah siswa per kelas antara 26-32 orang sehingga jumlah siswa secara keseluruhan kelas VIII adalah 150 orang, jumlah siswa kelas VIII paling banyak di antara kelas VII dan IX. Siswa di kelas XI A hingga IX E terdiri dari 21-32 orang per kelas sehingga jumlah siswa secara keseluruhan kelas IX adalah 133 orang. Sedangkan jumlah keseluruhan siswa di SMP N 2 Cepiring Kendal berjumlah 423 orang. Fasilitas Sekolah terdiri dari ruang kepala sekolah, ruang guru, ruang wakil kepala sekolah dan kesiswaan, ruang tata usaha, ruang UKS, ruang OSIS, ruang $\mathrm{BK}$, laboratorium IPA, ruang kelas VII, VIII, IX, ruang perpustakaan dan ruang komputer, toilet siswa-siswi, masjid dan kantin, serta ruang serba guna. Pengelolaan kurikulum di SMP N 2 Cepiring Kendal telah disesuaikan dengan kalender akademik yang di koordinir oleh wakil kepala sekolah bidang kurikulum sehingga sampai sekarang ini kegiatan sekolah menyangkut pengelolaan dan pelaksanaan kurikulum tidak mendapatkan masalah dalam pelaksanaannya. Kurikulum SMP N 2 Cepiring Kendal sebagai perwujudan dari kurikulum pendidikan dikembangkan sesuai dengan arahan Dinas Pendidikan. Sebelum kegiatan pembelajaran dimulai, seluruh siswa membaca doa dan Asmaul Husna yang di koordinir oleh guru mata pelajaran masing-masing. Kegiatan pembelajaran dimulai pada jam 07.00-14.00 dan dilaksanakan secara variatif selama enam hari sesuai dengan jadwal yang telah disepakati bersama.

\section{Kompetensi Pedagogik Guru IPS di SMP N 2 Cepiring Kendal}

Guru merupakan komponen utama dalam proses pembelajaran di sekolah yang menentukan keberhasilan siswanya. 
Berdasarkan Permendiknas No. 16 Tahun 2007, kompetensi pedagogik guru mata pelajaran di SMP/MTs terdiri dari 5 indikator antara lain: 1) Menguasai karakteristik siswa yang diampu; 2) Menguasai teori belajar dan prinsip-prinsip 3) Mengembangkan kurikulum; 4) Mengembangkan potensi peserta didik; 5) Memanfaatkan teknologi informasi dan komunikasi untuk pembelajaran. Proses belajar mengajar yang dilaksanakan dengan perencanaan yang matang dengan mempertimbangkan strategi, metode penyampaian dan media pembelajaran yang efektif dan efisien maka tujuan pembelajaran pun akan tercapai. Janawi (2011:65) kompetensi pedagogik adalah kemampuan guru berkenaan dengan penguasaan teoritis dan proses aplikasinya dalam pembelajaran, kompetensi pedagogis berkaitan langsung dengan penguasaan disiplin ilmu pendidikan dan ilmu lain yang berkaitan dengan tugasnya sebagai guru. Oleh karena itu seorang calon guru (pendidik) harus memiliki latar belakang pendidikan keguruan yang relevan dengan bidang keilmuannya.

Kompetensi pedagogik di SMP N 2 Cepiring Kendal sudah cukup bagus, para guru terus berusaha dalam meningkatkan kompetensi setiap tahunnya. Seperti pada saat pembelajaran daring seperti saat ini, guru-guru berusaha belajar menggunakan media belajar Online seperti Google classroom guna mempermudah pembelajaran dalam jaringan atau daring dengan siswa. Berdasarkan hasil penelitian, peneliti memperoleh data mengenai peran kompetensi pedagogik guru dalam mengembangkan keaktifan belajar siswa pada mata pelajaran IPS di SMP N 2 Cepiring Kendal Tahun Pelajaran 2020/2021. Hal tersebut di kemukakan melalui hasil wawancara serta observasi.

\section{Kemampuan Penguasaan Karakteristik Peserta didik}

Seorang guru dianggap menguasai karakteristik peserta didik dengan baik, apabila ia telah melakukan persiapan-persiapan sebelum melaksanakan proses mengajar. Salah satu indikator seorang guru dikatakan menguasai karakteristik siswa adalah dia sudah menyiakan cara pembelajaran yang cocok dengan karakter siswa. Demikian penguasaan bahan pembelajaran menjadi penting dalam proses pembelajaran dalam rangka melaksanakan pembelajaran agar apa yang diharapkan dapat tercapai dengan maksimal.

\section{Kemamuan Penguasaan Teori Belajar}

Kemampuan merencanakan program pembelajaran bagi seorang guru sangat penting, sebab guru harus mengetahui tujuan dari pembelajaran atau apa yang ingin dicapai dalam pembelajaran tersebut. Agar dapat merumuskan RPP, guru harus terlebih dahulu memahami arti dan tujuan RPP, serta menguasai isinya secara teoritis dan praktis. Oleh karena itu, kemampuan merencanakan suatu rencana pembelajaran merupakan landasan dari semua pengetahuan teoritis, keterampilan dasar, dan pemahaman yang mendalam tentang objek pembelajaran dan lingkungan pengajaran. Arti dari perencanaan pembelajaran adalah suatu prediksi guru terhadap kegiatan yang harus dilakukan siswa dalam proses pembelajaran. Kegiatan ini harus jelas ke mana siswa akan dibawa (tujuan), apa yang harus dipelajari siswa (isi materi pelajaran), bagaimana siswa belajar (metode dan teknik), dan bagaimana guru mengetahui bahwa siswa telah mencapainya (penilaian). Tujuan, isi, metode, teknik, dan evaluasi merupakan elemen utama yang harus diminimalkan dalam proses pembelajaran. Tujuan perancangan RPP adalah sebagai pedoman bagi guru untuk melakukan praktik atau tindakan mengajar di kelas. Oleh karena itu, apa yang dilakukan guru di kelas harus 
berasal dari program yang telah diatur sebelumnya agar tujuan yang diharapkan dapat tercapai. Jika guru membuat rencana pembelajaran setelah pembelajaran berlangsung, itu salah, karena rencana tersebut selalu mendahului pelaksanaan. Tujuan lain dari rencana pembelajaran adalah kebutuhan manajemen kelas. Berdasarkan uraian di atas, hal ini sangat menunjukkan bahwa sebelum mengajar, guru perlu membuat RPP sesuai dengan kebutuhan tugas guru.

Gambaran kemampuan guru di SMP N 2 Cepiring Kendal terkait dengan teori ajar yang ada dalam kurikulum sekolah dapat dilihat dari kemampuan guru ketika menyusun program pembelajaran. Sejalan dengan yang diungkapkan dari wawancara dengan Mardiyah (Guru IPS kelas VIII) SMP N 2 Cepiring Kendal diperoleh informasi bahwa di dalam penyampaian materi pembelajaran guru terlebih dahulu membuat perencanaan pembelajaran atau RPP Mardiyah menyatakan bahwa dalam merancang pembelajaran IPS disesuaikan dengan materi yang akan disampaikan tentunya diawali dengan pembuatan RPP, perangkat pembelajaran. Perancangan RPP tersebut yang nantinya akan disampaikan kepada siswa, agar mereka mengetahui apa yang akan mereka pelajari, lalu menanyakan kepada siswa dengan pembelajaran yang lalu dan menanyakan kepada siswa terhadap materi yang sudah dipelajari. Pada saat pembelajaran Online seperti sekarang, guru tetap melakukan hal yang sama, hanya berbeda media saja. Jika dahulu guru menjelaskan secara langsung, sekarang dengan adanya pandemi guru menjelaskan melalui Whatsapp group. Sebagaimana yang di ungkapkan oleh Tri Septi siswa kelas VII C di SMP N 2 Cepiring Kendal bahwa sebelum pembelajaran, terlebih dahulu guru mengecek kehadiran siswa, dilanjutkan dengan penjelasan secara singkat apa yang akan dipelajari hari ini lalu memberikan materi dan video pembelajaran, setelah itu siswa diberi kuis agar tetap ada tugas.

\section{Kemampuan Kurikulum}

Mengembangkan

Selama proses supervisi oleh kepala sekolah, guru IPS sudah melakukan dengan sistem multi arah dalam pembelajaran dan itu muncul dalam RPP, ketika dilakukan supervisi pada rencana pembelajaran terdapat metode diskusi kelompok, dalam praktik pelaksaannya pun juga ada seperti itu. Ketika diskusi kelompok itu berlangsung akan melibatkan siswa, interaksinya siswa juga aktif, terlihat pada keikutsertaan siswa membuat kesimpulan pada saat pembelajaran selesai, selain itu siswa di setiap kelompok juga melakukan kerja sama. Berdasarkan hal tersebut dapat dilihat bahwa guru IPS di SMP 2 Cepiring Kendal telah melaksanakan pengembangan materi belajar yang disesuaikan dengan kemampuan peserta didik. Diah Ekowati (Guru IPS Kelas VII) juga menyatakan bahwa:

Proses pembelajaran yang ia lakukan di kelas berjalan dengan kondusif, bagus dan lancar. Hal tersebut terlihat pada saat guru memasuki kelas siswa diam (anteng) serta bisa diajak kerja sama, selain itu sedari awal mereka mendengarkan pembelajaran dengan baik. Guna menghilangkan rasa jenuh yang muncul pada saat pembelajaran, guru melakukan ice breaking agar siswa bisa kembali fokus kepada materi pembelajaran. Selain itu guru juga melakukan pengembangan materi pembelajaran jadi tidak monoton menggunakan ceramah dan PPT saja.

Hal tersebut sejalan dengan pengamatan Peneliti bahwa selama proses pembelajaran di SMP N 2 Cepiring Kendal di setiap akhir pembelajaran guru tersebut selalu memberi arahan dan dukungan yang baik terhadap semua siswa, tidak memberikan hukuman kepada siswa yang menyimpang dari 
tugas yang diberikan dan apabila ada siswa yang belum mengerti pembelajaran guru menanggapi dengan memadai dan tenang, namun guru tetap menyediakan waktu untuk konsultasi masalah yang mereka hadapi melalui whatsapp chat.

\section{Kemampuan Mengembangkan Potensi Peserta Didik}

Bentuk kompetensi pedagogik, para guru di SMP N 2 Cepiring Kendal secara tidak langsung sudah melakukannya dengan cukup baik. Wawancara dengan Kepala Sekolah terhadap kinerja guru IPS terhadap pengembangan potensi peserta didik sudah dilaksanakan dengan sangat baik dengan mengikuti kualifikasi akademik dalam sebuah penelitian tindakan kelas, mengikuti kegiatan study banding, selain itu. Jadi secara formalnya ada bukti memiliki sertifikat sudah diakui pemangku kepentingan bahwa sudah memenuhi syarat-syarat tertentu. Untuk guru IPS di SMP N 2 Cepiring Kendal sudah mendapatkan pengakuan pemerintah dengan memiliki sertifikat profesionalisme guru, maka dapat dikatakan keprofesionalitasan guru IPS di SMP N 2 Cepiring Kendal sudah dikatakan baik. Selain itu juga guru terus mengikuti perkembangan dan kemajuan zaman dari berbagai sumber, baik dari media elektronik maupun media cetak. Guru juga selalu melakukan pertukaran informasi melalui kegiatan MGMP baik MGMP sekolah maupun MGMP luar sekolah yang tentunya akan menghasilkan peningkatan kemampuan dalam mengajar.

Sejalan dengan hasil wawancara guru, dan termasuk juga hasil pengamatan yang telah penulis laksanakan, dapat dikatan bahwa pengembangan pedagogik guru IPS di SMP N 2 Ceppiring Kendal sudah dilaksanakan dengan cukup baik, terlihat dari kegiatankegiatan yang dilakukan guru guna menunjang kemampuan mengajarnya. Kemampuan guru menunjang pembelajaran tidak kurang dari dukungan pihak sekolah bahwasannya Kepala Sekolah meminta semua guru di SMP N 2 Cepiring dapat mengasah kemampuannya dengan mengikuti kegiatan MGMP, terlebih guru mata pelajaran IPS.

\section{Kemampuan Memanfaatkan Teknologi Informasi dan Komunikasi}

Guru dituntut memiliki kemampuan untuk menggunakan teknologi informasi dan komunikasi dalam melaksanakan pembelajaran dalam jaringan atau daring (khususnya internet) seperti saat terjadi pandemi seperti ini sehingga guru dapat menggunakan segala macam ilmu pengetahuan, teknologi dan informasi untuk melaksanakan tugas pokok mengajar dan membentuk kemampuan siswa. Sehubungan dengan hal tersebut, berdasarkan hasil pengamatan penulis selama melihat proses belajar mengajar yang dilaksanakan guru IPS di SMP N 2 Cepiring kendal ditemukan bahwa dalam proses pembelajaran, guru hampir selalu menggunakan laptop, Video, dan fasilitas teknologi pembelajaran lainnya. Hal tersebut menandakan bahwa guru IPS di SMP N 2 Cepiring Kendal memiliki kemampuan dalam menggunakan sumber belajar sesuai dengan tingkatan zaman.

Metode dan model pembelajaran tidak lagi menggunakan model pembelajaran tradisional (dimana guru menjelaskan dan siswa mendengarkan), tetapi guru menuntun siswa dalam proses pembelajaran dengan memanfaatkan teknologi secara aktif. Oleh karena itu, guru tidak hanya perlu menggunakan sumber belajar yang ada di sekolah, seperti membaca buku teks, tetapi juga perlu mempelajari berbagai sumber, seperti majalah, koran, internet, TV dan radio. Sebagaimana yang telah dijelaskan, salah satu kemampuan guru dalam menggunakan alat peraga dan teknologi pembelajaran 
menunjukkan bahwa guru IPS di SMP N 2 Cepiring Kendal dapat menggunakan sumber belajar, seperti menggunakan teknologi informasi sebagai sumber belajar. Pada saat pembelajaran guru sering menggunakan LCD. Sumber belajar merupakan sarana pembelajaran yang efektif dalam menyampaikan informasi kepada siswa, oleh karena itu diperlukan kemampuan dan kelihaian pengelola pembelajaran, dalam hal ini guru harus menggunakan sumber belajar sebagai media yang akan membantu guru untuk lebih mudah berkomunikasi. Mempelajari informasi dan memotivasi siswa untuk belajar lebih aktif. Kemampuan seorang guru menggunakan media/ sumber belajar merupakan pekerjaan yang sangat ditekan oleh guru profesional seperti mengenal dan memilih, dan menggunakan media, membuat alat-alat bantu pembelajaran sederhana dan menggunakan perpustakaan dalam proses pembelajaran.

Kemampuan menggunakan sumber belajar oleh guru terlihat dari kesiapan guru IPS dalam mempersiapkan perangkat pembelajaran. Perangkat itu yang nantinya akan digunakan sebagai panduan penggunaan sumber belajar yang seperti apa. Sependapat dengan hal tersebut, Azzahra (Siswa kelas IX E) menyatakan bahwa sumber belajar yang mereka gunakan adalah buku paket, internet, LKS yang bisa dikerjakan di rumah pada saat pandemi seperti ini. Sejalan dengan hasil wawancara siswa serta guru, dan termasuk juga hasil pengamatan yang telah penulis laksanakan, dapat dikatan bahwa pembelajaran IPS di SMP N 2 Ceppiring Kendal sudah menggunakan sumber belajar yang beraneka ragam mulai yang sederhana seperti buku hingga yang paling umum seperti video dan ppt, kendati demikian dengan kemampuan guru dalam mengelola kelas, pembelajaran menurut siswa menjadi menarik sebab sumber belajar yang digunakan tidak membosankan serta mudah digunakan.

\section{Keaktifan Belajar Siswa dalam Proses Pembelajaran IPS di SMP N 2 Cepiring Kendal}

Keaktifan belajar siswa SMP N 2 Cepiring Kendal terlihat dari feedback atau timbal balik siswa terhadap materi pelajaran yang diberikan oleh guru. Keaktifan siswa juga dapat terlihat pada saat melakukan diskusi, siswa aktif bertanya dan berani untuk menjawab pertanyaan yang diberikan. Keaktifan siswa dalam proses pembelajaran terlihat dari pengumpulan tugas oleh siswa yang selalu tepat waktu dan tidak pernah terlambat. Pada saat pembelajaran daring seperti ini, guru melaksanakan pembelajaran dengan menggunakan whatsapp grup. Penjelasan serta sesi tanya jawab dilaksanakan sesuai jadwal pelajaran melalui grup WA. Setelah melaksanakan pembelajaran siswa diberi tugas individu untuk mengetahui tingkat serapan materi pembelajaran yang telah dilaksanakan. Pemberian tugas dilakukan via WAgroup dan pengumpulan tugas dilaksanakan beberapa hari setelah pemberian tugas dengan cara diantar ke sekolah. Siswa terlihat sangat aktif dapat dilihat dari semangat siswa dalam mengumpulkan tugas. Selain itu, selama proses pembelajaran daring siswa yang berpartisipasi dalam proses pembelajaran juga cukup banyak. Walaupun di tengah pandemi dan pembelajaran dari rumah keaktifan siswa dalam mengikuti pembelajaran juga tidak luput dari peran guru yang selalu berusaha membuat siswa nyaman selama proses pembelajaran. Di tengah kendala pembelajaran dari rumah siswa tetap semangat untuk melaksanakan pembelajaran, hal tersebut tidak luput dari upaya guru yang selalu mendorong siswa untuk selalu berusaha menjadi lebih baik setiap harinya. Hasil wawancara dengan guru mata pelajaran IPS 
untuk menilai keaktifan belajar siswa selain dengan melihat tugas yang telah dikerjakan, guru juga dapat melihat keaktifan siswa dengan cara mengamati tingkah laku siswa selama proses belajar mengajar berlangsung. Sebagaimana yang diungkapkan oleh Diah Ekowati, guru IPS kelas VII SMP N 2 Cepiring Kendal yang menyatakan bahwa saat pembelajaran guru berusaha melibatkan siswa, sehingga siswa menjadi aktif terlihat pada saat siswa mau menanggapi saat guru melempar pertanyaan kemudian siswa dapat berperan aktif menyebutkan contoh saat guru menjelaskan pelajaran tentang sekitar tempat tinggal mereka. Keaktifan siswa SMP N 2 Cepiring Kendal sesuai dengan pendapat Nana Sudjana (2005:72) yang menyatakan bahwa keaktifan siswa dapat dilihat dari keikutsertaan siswa dalam melaksanakan tugas belajarnya, terlibat dalam memecahkan masalah, bertanya kepada siswa lain atau guru apabila tidak memahami persoalan yang dihadapi, berusaha mencari berbagai informasi yang diperlukan untuk memecahkan masalah, melatih diri dalam memecahkan masalah atau soal, serta menilai kemampuan diri sendiri dan hasil-hasil yang diperoleh.

Pada saat pembelajaran normal, biasanya siswa selalu bersemangat saat melaksanakan pembelajaran IPS, hal tersebut karena guru selalu menggunakan metode belajar yang berbeda. Contoh pada materi ekonomi, siswa diajak ke pasar untuk mengamati kegiatan yang ada di pasar, pembelajaran di luar sekolah membuat siswa bersemangat dalam belajar, sebab mereka merasa seperti sedang bermain, bukan lagi belajar. Terkait dengan peran kompetensi pedagogik guru dalam dan keaktifan belajar siswa, maka peneliti menjelaskan keaktifan yang direalisasikan dengan keterlibatan siswa dalam mengikuti proses pembelajaran di SMP $\mathrm{N} 2$ Cepiring Kendal tahun pelajaran 2020/2021. Keaktifan siswa dapat dilihat dari keikutsertaan siswa dalam proses pembelajaran dengan cara menyampaikan pendapat, mampu bertanya terkait pembelajran,siswa mampu melakukan diskusi dengan kelompok, kemudian mampu mempresentasikan hasil kerja kelompok, dan tercipta suasana kelas dengan siswa yang aktif.

Perhatian siswa di SMP N 2 Cepiring Kendal dalam mengikuti proses pembelajaran berdasarkan hasil wawancara dengan guru IPS sebagai berikut: 1) tanggapan siswa terhadap proses pembelajaran bagus walaupun tidak $100 \%$ tetapi ada beberapa anak yang menanggapi; 2) banyak siswa yang aktif dengan banyak yang menanggapi pembelajaran; 3) siswa merasa suka pada saat disuruh lihat globe; 4) keaktifan siswa dapat terlihat dari keseriusan siswa mengerjakan tugas. Atas dasar temuan inilah, dapat peneliti simpulkan bahwa Guru di SMP N 2 Cepiring Kendal memiliki peranan yang sangat penting dalam menngembangkan keaktifan belajar siswa dengan tetap melaksanakan komponen pedagogik guru yang harus dimilikinya, antara lain kemampuan menguasai materi, memahami tujuan pembelajaran, mengembangkan materi, mengembangkan keprofesionalan, serta kemampuan dalam memanfaatkan teknologi informasi dan komunikasi. Komponen kompetensi pedagogik inilah saling berkaitan dalam proses pembelajaran dalam hal ini keaktifan siswa menjadi acuan bagi guru IPS dalam peranan kompetensi pedagogik.

\section{Kendala Guru IPS dalam Mengerjakan Materi melalui Pembelajaran dalam Jaringan di SMP N 2 Cepiring Kendal}

Kendala Guru IPS dalam mengajarkan materi pembelajaran dalam jaringan berdasarkan hasil observasi yang telah peneliti lakukan, ditemukan beberapa kendala yaitu pada saat guru melakukan pembelajaran daring koneksi sering terputus karena jaringan 
internet yang tidak stabil. Pada penelitian ini, hasil pengamatan yang telah peneliti laksanakan dengan hasil wawancara memiliki kesinambungan. yaitu salah satu penyebab belum efektifnya penggunaan teknologi informasi dan komunikasi dalam setiap pembelajaran IPS di SMP N 2 Cepiring Kendal adalah karena kendala yang berasal dari kurangnya sarana prasarana sekolah serta keterbatasan kemampuan guru dalam mengexplore media pembelajaran yang menggunakan teknologi.

\section{a. Kendala pada aspek pengembangan kompetensi pedagogik secara berkelanjutan}

Kendala guru pada pengembangan kompetensi pedagogik secara berkelanjutan dapat dilihat dari kurang aktifnya guru dalam melakukan tindakan reflektif penelitian seperti menulis penelitian tindakan kelas atau PTK, hal tersebut karena keterbatasan waktu yang dimiliki oleh guru, sehingga tidak semua guru dapat meluangkan waktu untuk melakukan penelitian. Guru IPS tidak terbiasa dalam menulis PTK, hal tersebut diakibatkan karena selama berada di sekolah, guru sudah disibukkan dengan kegiatan belajar mengajar serta pembuatan perangkat dan media belajar yang dikerjakan setiap hari. Hal ini membuat guru IPS kurang mampu dalam penulisan PTK namun guru IPS lebih mengedepankan persiapan perangkat pembelajaran dan media belajar guna proses pembelajaran dapat tercipta suasana kelas yang aktif oleh siswa tertarik dengan pembelajaran IPS yang telah disiapkan.

\section{b. Kendala pada aspek pemanfaatan teknologi informasi dan komunikasi}

Kendala pada pemanfaatan teknologi informasi dan komunikasi sangat terlihat saat pembelajaran daring seperti saat ini. Hal tersebut lantaran keterbatasan kemampuan guru untuk mengembangkan diri dan masih belum menggunakan teknologi menyeluruh dalam proses pembelajaran. Sarana dan prasarana pembelajaran khususnya teknologi yang dimiliki sekolah belum terpakai maksimal pada proses pembelajaran karena faktor keadaan ekonomi siswa yang tidak semuanya memiliki HP dan kuota internet, selain itu guru-guru juga masih kesusahan mengakses pembelajaran daring dengan menggunakan aplikasi yang rumit.

Upaya-upaya yang dilakukan untuk meningkatkan kompetensi pedagogik guru dan kekatifan belajar siswa pada mata pelajaran IPS melalui pembelajaran dalam jaringan melalui kompetensi pedagogik guru merupakan suatu kebutuhan bagi seorang guru guna meningkatkan mutu Pendidikan. Kendati demikian, memang benar adanya jika dikatakan mutu Pendidikan tidak hanya tergantung oleh guru saja, melainkan beberapa komponen Pendidikan lainnya, akan tetapi kemajuan dalam proses belajar mengajar sejauh ini masih tergantung dengan kemampuan guru dalam menerapkan standar kompetensi yang harus dimiliki serta kompetensi profesional yang selalu lekat dengan guru. mengembangkan keaktifan belajar siswa pada mata pelajaran IPS di SMP $\mathrm{N} 2$ Cepiring Kendal adalah dengan cara mengikutsertakan guru dalam kegiatan seminar dan pelatihan yang di adakan di dalam dinas pendidikan dan di luar dinas, agar guru memiliki wawasan yang semakin luas. Peningkatan profesionalisme guru melalui PKG (pemantapan kerja guru) melalui wadah tersebut para guru di arahkan untuk mencari berbagai pengalaman mengenai metodologi pembelajaran dan bahan ajar yang di tetapkan dalam kelas dan meningkatkan kesejahteraan guru, kesejahteraan guru tidak dapat di abaikan karena merupakan salah satu faktor penentu dalam meningkatkan kinerja guru yang secara langsung terhadap mutu 
pendidikan. Selain itu kegiatan MGMP juga berperan aktif sebagai wadah tukar informasi sesama guru.

Beberapa hal yang dilakukan guru serta sekolah untuk meningkatkan kompetensi pedagogik guru antara lain meningkatkan sarana prasarana pendukung pembelajaran, memfasilitasi guru dalam proses pencarian sumber belajar baru, memfasilitasi kegiatankegiatan yang mendukung perkembangan kompetensi guru. Berdasarkan yang peneliti amati, sekolah sangat mendukung peningkatan kompetensi pedagogik bagi guru karenya sangat pentingnya tingkat perkembangan profesional bagi guru untuk bekal dalam menghadapi perkembangan zaman seperti sekarang ini dengan memberikan kesempatan seluas-luasnya bagi guru yang ingin mengembangkan kompetensi yang dimilikinya sehingga guru akan terus berkembang ke arah peningkatan kompetensi pedagogik guru. Dukungan dari pihak sekolah ini akan berpengeruh dalam mutu pendidikan di sekolah bahwasannya kemajuan yang didapatkan oleh guru inilah yang akan membawa perubahan bagi sekolah.

\section{SIMPULAN}

Guru IPS di SMP N 2 Cepiring Kendal merupakan guru-guru yang memiliki kompetensi pedagogik dengan memiliki lima indikator yang saling berkaitan dalam proses pembelajaran. Kompetensi pedagogik tersebut terlihat dari kegiatan belajar mengajar yang dilaksanakan oleh guru IPS. Kompetensi pedagogik guru dalam mengembangkan keaktifan belajar siswa pada mata pelajaran IPS di SMP N 2 Cepiring Kendal memiliki peran yang sangat penting yang direalisasikan berdasarkan kompetensi yang harus dimiliki oleh guru yaitu kemampuan menguasai karakteristik siswa, kemampuan menguasai teori belajar, kemampuan mengembangkan kurikulum, kemampuan mengembangkan potensi peserta didik dan kemampuan memanfaatkan teknologi informasi dan komunikasi. Keaktifan siswa SMP N 2 Cepiring Kendal dalam proses pembelajaran terlihat dari kemampuan siswa menangkap materi pembelajaran atau respons dari siswa dapat dilihat dari berbagai hal seperti mendengarkan, memperhatikan, berdiskusi, kesiapan siswa, keberanian siswa, memecahkan soal, dan mengutarakan pendapat pada saat proses belajar mengajar.

Kendala Guru IPS dalam mengajarkan materi pembelajaran dalam jaringan yaitu pada saat guru melakukan pembelajaran daring koneksi sering terputus karena jaringan internet yang tidak stabil, kendala yang berasal dari kurangnya sarana prasarana sekolah serta keterbatasan kemampuan guru dalam mengexplore media pembelajaran yang menggunakan teknologi. Kerja sama dari semua pihak termasuk pihak sekolah, keluarga dan masyarakat sangat diperlukan agar pengimplementasian kompetensi profesional guru dalam peningkatan hasil belajar berjalan lancar dan mencapai tujuan yang diinginkan.

\section{DAFTAR PUSTAKA}

Janawi. 2010. Kompetensi Guru (Citra Guru Profesional). Bandung: Alfabeta.

Peraturan Pemerintah Republik Indonesia No. 16 Tahun 2007 tentang Standar Kualifikasi Akademik dan Kompetensi Guru

Ramayulis. 2013. Etika dan Profesi Keguruan. Jakarta: Kalam Mulia.

Sudjana, Nana. 2005. Dasar-Dasar Proses Belajar Mengajar. Jakarta: CV Rajawali.

Sugiyono. 2010. Metode Penelitian Pendidikan Pedekatan Kuantitatif, Kualitatif, dan $R \& D$. Bandung: Alfabeta. 
Tri Wulan Sari, dkk / Sosiolium 3 (1) (2021)

Sukanti. 2008. "Meningkatkan Kompetensi Guru Melalui Pelaksanaan Tindakan Kelas. Jurnal Pendidikan Akutansi Indonesia, Vol. VI, No. 1.
Undang-undang Republik Indonesia Nomor 14 tahun 2004 tentang Guru dan Dosen Zamroni, 2001. Pendidikan Untuk Demokrasi. Yogyakarta: Bilgraf Publising. 